\title{
Blood Transfusion Strategies in Elective Vascular Surgery
}

\section{Mannova $\mathbf{J}^{1 *}$, Silhart $\mathbf{Z}^{2}$ and Prokes ${ }^{3}$}

${ }^{1}$ Department of Anaesthesiology and Resuscitation, Havlickuv Brod, Czech Republic

${ }^{2}$ Department of Surgery, Faculty Hospital Brno, Masaryk University, Czech Republic

${ }^{3}$ Faculties of Electrical Engineering and Communication, Brno University of Technology, Czech Republic

\begin{abstract}
Autotransfusion techniques used in vascular surgery: intraoperative cell salvage (ICS) and acute normovolemic haemodilution (ANH), are evaluated in this article, especially their effectiveness in the reduction of allogeneic blood transfusions and cost.

In comparison with ICS, ANH does not need any special equipment, is more accessible and cheaper, but the other method, ICS, is more adopted by vascular surgeons and anaesthetists. Even if ICS is preferred to ANH, only one study among the randomized studies confirmed the convincing benefit of using the cell salvage technique, and only 2 non-randomized studies had similar results, moreover, meta-analyses of these studies have not resolved the dispute over the efficiency of ICS. Only three meta-analyses assessing ICS in a subpopulation of patients who underwent abdominal aortic aneurysm surgery showed a decrease in the use of allogeneic blood and improvement of clinical outcomes.
\end{abstract}

ANH in vascular surgery was evaluated in 6 randomized studies and 1 retrospective study. There was no study, except one, which would evaluate ANH as the only autotransfusion method in vascular surgery. ANH was assessed in combination with ICS and 3 randomized studies confirmed that this combination could be effective in the achievement of the reduction in exposure to allogeneic blood. Because ANH can have an impact on microcirculatory and macrocirculatory levels, two studies evaluated it from this point of view, but without any significant results.

For the future, both ANH and ICS can have a potential to save allogeneic blood and money but positive results depend on blood loss and the type of elective infrarenal aortic surgery. ANH should be evaluated separately and in greater detail. Although the general risks of blood transfusion have been reduced during recent years, the risk of the transmission of infectious diseases, bacterial, fungal as well as viral, transfusion reactions, immunosuppression and postoperative infectious complications still remains. To avoid allogeneic transfusion, autotransfusion techniques are preferred. They include the intraoperative cell salvage technique (ICS), acute normovolemic haemodilution (ANH) and preoperative blood donation. Each of the autotransfusion techniques can be used for vascular surgery but some of them have more often been adopted by vascular surgeons. The most popular technique in vascular surgery seems to be intraoperative cell salvage whereas acute normovolemic haemodilution is not used as frequently. Techniques (ICS, ANH), their advantages and disadvantages as well as their effectiveness in the reduction of cost and allogeneic blood transfusions in elective vascular surgery are evaluated in this article.

Keywords: Blood transfusion strategies, Elective vascular surgery

\section{Intraoperative Cell Salvage (ICS)}

Cell salvage as the preferred method in infrarenal surgery is universally available, but, on the other hand, it is necessary to have special equipment and trained staff while a theoretical disadvantage of ICS is the removal of plasma active functional coagulation factors, thus increasing coagulopathy [1]. Two types of devices for intraoperative autotransfusion have been developed. The first type collects the shed blood, washes and centrifugally separates out the red blood cells (RBCs), and then returns them back. During this process, platelets and clotting factors are also removed [2-5]. The second major type of autotransfusion device for hemofiltration alone collects the blood, filters it, and re-infuses it. These devices return all of the blood elements, including the platelets and the coagulation factors, but they do not remove any potentially harmful debris and contaminants [2-6]. The justification of using cell salvage in vascular surgery has two reasons: the first one is to avoid the need to transfuse allogeneic blood with all the involved risk, and the second one is cost-effectiveness because aortic surgery is associated with higher blood loss within surgery [7]. The main cited published studies, both randomized and retrospective non-randomized studies which assess the cell-salvage technique in infrarenal aortic surgery are mentioned in the following text.

\section{Randomized Studies with ICS}

Clagett et al. [8] published a randomized trial of intraoperative transfusion during aortic surgery. In this study, 100 patients who underwent AAA repair or aortofemoral bypass for occlusive disease were randomized to ICS (cell salvage) and control group. No significant differences were found in estimated blood loss, allogeneic blood transfusion (unit administered intraoperatively, postoperatively, and total), proportion of patients not receiving allogeneic blood (34\% of patients randomized to ICS and $28 \%$ in control patients), postoperative

*Corresponding author: Jitka Mannova, Department of Anaesthesiology and Resuscitation, Havlickuv Brod, Polni 17, 59102 Zdar nad Sazavou 2, Czech Republic, Tel: +420604232770; E-mail: j.mann@seznam.cz

Received June 25, 2014; Accepted October 25, 2014; Published November 15,2014

Citation: Mannova J, Silhart Z, Prokes (2014) Blood Transfusion Strategies in Elective Vascular Surgery. J Blood Disorders Transf 5: 233. doi: 10.4172/2155 9864.1000233

Copyright: @ 2014 Mannova J, et al. This is an open-access article distributed under the terms of the Creative Commons Attribution License, which permits unrestricted use, distribution, and reproduction in any medium, provided the original author and source are credited. 
haemoglobin levels and complications (cardiac, septic, stroke, venous thromboembolism, gastro-intestinal bleeding, pancreatitis, death). The authors found no benefit of intraoperative autotransfusion (cell-salvage technique) in patients undergoing elective infrarenal aortic surgery.

Spark et al. [9] published another prospective randomized study in which they assessed the postoperative outcomes of patients in elective infrarenal abdominal surgery. Autologous $(n=23)$ and homologous blood transfusion $(n=27)$ groups were compared. In the autologous group the cell salvage autotransfusion device was used. There was no difference in perioperative mortality, postoperative development of SIRS and chest sepsis. The statistically significant reduction was in the length of hospital stay ( 9 vs. 12 days, $\mathrm{p}<0.050$ ) and an increased risk of infection for patients who received 3-4 units of homologous blood compared to those who received similar amounts of autologous blood.

Kelley-Patterson and colleagues [10] estimated intraoperative blood loss and transfusion requirements in four randomized groups of patients, all of whom underwent infrarenal abdominal aortic bypass operations $(\mathrm{n} 1=21, \mathrm{n} 2=19, \mathrm{n} 3=18, \mathrm{n} 4=18$ patients, group 1-3 with the Cell Saver Device). The authors found that $48 \%$ of the patients in group 1 (AAA repair/a tube graft) and $61 \%$ of the patients in group 3 (occlusive disease/aortofemoral or biiliac bypass) had Cell Saver return volumes of less than $500 \mathrm{ml}$. In group 2 (AAA repair/bifemoral or biiliac bypass) only $16 \%$ of the patients had Cell Saver return volumes of less than $500 \mathrm{ml}$. In group 4 the Cell Saver Device was not used. The greatest need for intraoperative homologous blood administration had patients in group 2 (47\%). Transfusion requirements for the other groups were much lower: $24 \%$ in group $1 ; 11 \%$ in group 3 and $6 \%$ in group 4 . In view of these results the authors concluded that no routine set-up and use of the Cell Saver Autotransfusion Device were necessary in patients undergoing any type of elective aortic surgery for either AAA disease or occlusive disease because the use of homologous blood was not altered.

In contrast to the studies mentioned above, the results of the study by Mercer were positive for the cell salvage technique. Mercer et al. [11] randomized 40 patients operated on for AAA to the intraoperative autotransfusion group (cell salvage - RBC washing technique) and 41 patients who underwent surgery with perioperative homologous blood transfusion in the single-center study. Based on the result of this study; significantly fewer patients in the intraoperative autotransfusion group received homologous autotransfusion, 21 vs. 31 ( $\mathrm{p}=0.038)$, and the median blood requirement per patient was 2 units lower $(\mathrm{p}=0.012)$ in the autotransfusion group. There was a higher incidence of chest infection ( 12 vs. 5 patients, $\mathrm{p}=0.049)$ and SIRS ( 20 vs. 9 patients, $\mathrm{p}=0.020)$ in the homologous blood transfusion group.

\section{Retrospective Studies with ICS}

Quriel et al. [6] used an autotransfusion device that administers unwashed, filtered blood (200 patients undergoing aortic reconstructive surgery). The authors found that using it was safe and efficacious, served as an alternative to homologous blood transfusion, and diminished the need for additional homologous blood transfusion. The other authors estimated the efficiency of RBC washing devices. Huber et al. [12] included 173 cases in their study. No difference was seen in the blood transfusion requirement between patients with aneurysm and those with aortoiliac occlusive disease. Even if the Cell Saver was used, $73.8 \%$ of patients required homologous blood transfusion with a mean of $3.0 \pm 3.1$ units being transfused during the hospital stay. Goodnough and colleagues [13] followed 184 patients who underwent elective AAA repair to evaluate the cost-effectiveness of the cell salvage technique. Blood loss on average was $1748 \pm 1236 \mathrm{ml}$ in these patients.
Thirty-two (89\%) of the 36 patients, who did not receive any Cell Saver blood, required transfusions. Of the patients who had Cell Saver blood salvaged a similar percentage (67\%) required homologous transfusions. Cost savings could only be demonstrated in $22 \%$ of the patients who underwent surgery. The investigators concluded that intraoperative cell salvage was beneficial for patients who had intraoperative blood losses of $1000 \mathrm{ml}$ or more and Cell Saver volumes returned of $750 \mathrm{ml}$ or more. Tawfick et al. [14] published a retrospective cohort study with 187 patients who underwent open repair of AAA. One group of patients received an autotransfusion system (cell salvage) and the second group allogeneic transfusion. $61 \%$ in the autologous group required 2 or less units of allogeneic blood and all the control patients received 3 or more units of allogeneic blood. Allogeneic transfusion in the autotransfusion group patients decreased significantly $(\mathrm{p}<0.0001)$. In this study the cell salvage technique markedly reduced the amount of allogeneic blood and was associated with the reduced intensive care and postoperative hospital stay.

\section{Conclusion Regarding Randomized and Retrospective Studies with ICS in Aortic Surgery}

Based on the results of these papers, only one study among the randomized studies confirmed the convincing benefit of using the cell salvage technique (Mercer [11]) and only 2 non-randomized studies (Quriel [6]-unwashed filtered blood, Tawfick [14]) provided similar results (Table 1).

The results of the study by Mercer were positive for the cell salvage technique and confirmed that the use of the cell saver technique effectively reduced the need for homologous autotransfusion and was associated with reduced incidence of postoperative SIRS and infective

\begin{tabular}{|c|c|c|}
\hline Study & $\begin{array}{l}\text { Savings in allogeneic } \\
\text { blood transfusion }\end{array}$ & Cost-effectiveness \\
\hline $\begin{array}{l}\text { Claget [8] } \\
\text { randomized control st } \\
\mathrm{N}=100\end{array}$ & No & No \\
\hline $\begin{array}{l}\text { Spark [9] } \\
\text { randomized control st } \\
\mathrm{N}=50\end{array}$ & No & $\begin{array}{c}\text { No } \\
+ \text { increased risk of } \\
\text { infection for } \\
\text { patients who received } \\
\text { 3-4 units of allogeneic } \\
\text { blood }\end{array}$ \\
\hline $\begin{array}{l}\text { Kelley-Patterson [10] } \\
\text { randomized control st } \\
\qquad \mathrm{N}=76\end{array}$ & No & No \\
\hline $\begin{array}{l}\text { Mercer [11] } \\
\text { randomized control st } \\
\mathrm{N}=81\end{array}$ & $\begin{array}{c}\text { Yes } \\
21 \mathrm{AUT} \text { vs. } 31 \mathrm{ALL} \\
(p=0.038)\end{array}$ & $\begin{array}{c}\text { Yes } \\
+ \text { reduction in the } \\
\text { incidence of chest } \\
\text { sepsis and occurrence } \\
\text { of SIRS }\end{array}$ \\
\hline $\begin{array}{c}\text { Quriel [6] } \\
\text { retrospective st } \\
\text { Unwashed RBC } \\
\mathrm{N}=200\end{array}$ & $\begin{array}{l}\text { Yes } \\
\text { AUT group } 0.6+/-0.1 \text { units } \\
\text { ALL group } 3.4+/-0.1 \text { units } \\
p<0.001\end{array}$ & $\begin{array}{c}\text { Yes } \\
\text { \$288 savings }\end{array}$ \\
\hline $\begin{array}{l}\text { Huber [12] } \\
\text { retrospective st } \\
\mathrm{N}=173\end{array}$ & No & No \\
\hline $\begin{array}{l}\text { Goodnough [13] } \\
\text { retrospective st. } \\
\mathrm{N}=184\end{array}$ & No & $\begin{array}{c}\text { beneficial when blood } \\
\text { losses of } 1000 \mathrm{ml} \text { or } \\
\text { more }\end{array}$ \\
\hline $\begin{array}{l}\text { Tawfick [14] } \\
\text { retrospective cohort st } \\
\mathrm{N}=187\end{array}$ & $\begin{array}{c}\text { Yes } \\
2 \text { or less units AUT vs. } 3 \\
\text { or more units ALL } \\
p<0.0001\end{array}$ & $\begin{array}{c}\text { Yes } \\
+ \text { shorter ICU, hospital } \\
\text { stay }\end{array}$ \\
\hline
\end{tabular}

AUT: Autotransfusion group; ALL: Allogeneic group

Table 1: Cell salvage in aortic infrarenal surgery. 
complications. In comparison with the other three randomized studies the specificity of this study was that Mercer and colleagues assessed only a subpopulation of patients in infrarenal aortic surgery, i.e. those who underwent abdominal aortic aneurysm repair.

The advantage of the retrospective non-randomized studies was that the amount of patients who were estimated was higher but their results were similarly controversial. Quriel et al. found a positive benefit of ICS in saving both allogeneic blood and money, however, the autotransfusion device, used in this study, administered unwashed filtered blood in contrast to the other non-randomized studies in which the second major type of autotransfusion device (RBC washing device) was used.

Other benefits of randomized and non-randomized studies should be mentioned. Spark et al. proved increased risk of infection complications in patients who received 3-4 units of allogeneic and Mercer et al. confirmed a reduction in the frequency of chest sepsis and the occurrence of SIRS in the ICS group. Moreover, Tawfick et al. confirmed shorter ICU and hospital stay in the ICS group. Both a decrease in postoperative infection complications and a shorter ICU or hospital stay are seen as other advantages of the use of the autotransfusion technique.

\section{Meta-Analyses}

In 2004, Freischlag [2] published a review dedicated to intraoperative blood salvage in vascular surgery. The studies, mentioned in this work, are a mixture of prospective and retrospective evaluations of cell salvage techniques (Kelley-Patterson et al., Quriel et al., Goodnough et al., Huber et al.) $[6,10,12,13]$. The author summarized that the use of cell salvage techniques in vascular surgery had the potential to prevent the use of homologous blood transfusions, but in reality that does not appear to occur. The risk of transmitting diseases by blood transfusions is sufficiently low and the use of the Cell Saver does not appear to have an impact on the individual patients. Cost savings only occur when there is a high blood loss.

In the same year, 2004, Alvarez et al. [15] assessed only randomized controlled trials involving cell salvage and vascular surgery with similar results. The authors identified five randomized trials in MEDLINE, EMBASE and the Cochrane library (Clagett et al., Spark et al., Clagett et al., Kelley-Patterson et al.). [8-10]. These studies compared the cell salvage group and the control group in abdominal vascular surgical procedures. In this meta-analysis of randomized controlled trials the authors were unable to demonstrate that cell salvage decreased exposure to allogeneic red cells. In infrarenal AAA surgery the risk ratio (the risk of receiving at least one unit of allogeneic red cells) was 0.37 [95\% confidence interval (CI) of 0.06 to 2.36]. In elective aortofemoral bypass surgery the risk ratio was 0.97 (95\% CI of 0.366 to 1.42 ). The pooled risk ratio for cell salvage in vascular surgery was 0.67 (95\% CI of 0.35 to 1.28$)$.

The remaining 3 meta-analyses evaluated cell salvage as an autotransfusion method in a subpopulation of patients who underwent abdominal aortic aneurysm (AAA) surgery. In 2007 Tagaki et al. [16] identified 4 randomized controlled trials including data for 292 patients (Spark et al. Clagett et al. Wong et al. Mercer et al.) [7-9,11,17]. Two out of 4 sensitivity analyses demonstrated statistically non-significant results favouring intraoperative autotransfusion. Pooled analysis showed a statistically significant $37 \%$ reduction in the risk of allogeneic blood transfusion with intraoperative autotransfusion compared with control group (risk ratio, 0.63; 95\% confidence interval, 0.41-0.95; $\mathrm{p}=0.03$ ). Based on this a meta-analysis of randomized controlled trials in AAA surgery, intraoperative autotransfusion reduces the risk of allogeneic blood transfusion in elective infrarenal AAA repair. Later, in 2011, Tavare et al. [18] did another meta-analysis of randomized controlled trials with the aim of assessing the improvement of clinical outcomes. The authors found that the use of intraoperative cell salvage did not cause an increase in morbidity or mortality when compared with the standard practice of transfusion of allogeneic blood and may actually improve some clinical outcomes: shorter stay in ICU, shorter hospital stay, reduction in chest sepsis, occurrence of SIRS in elective AAA surgery. According to these authors intraoperative cell salvage is a useful and safe strategy. In the third review published by Shantikumar et al. [19]. The authors identified 23 studies in order to delineate the role of cell salvage in reducing allogeneic blood use in open AAA repairs. As the authors wrote, even if some data were conflicting, cell salvage appeared to reduce the overall use and exposure allogeneic blood, and reduced the length of ICU and hospital stay after elective AAA repairs. In conclusion we may say that the results of single studies are full of contradictions, and meta-analyses of these studies have brought no solution to the dispute over the efficiency of the cell salvage technique in vascular surgery.

\section{ToSummarize the Use of Cell Salvage as Autotransfusion Technique in Aortic Surgery}

Only a few of the studies showed the Cell Saver device to be beneficial (Table 1). Some papers seem to suggest that the only purpose of setting up the Cell Saver Autotransfusion Device is to provide the surgeon with peace of mind in the event of sudden and unforeseen blood loss, such as when the aorta, vena cava, or renal vein is injured. On the other hand, it should be said that the use of cell salvage techniques in vascular surgery can have the potential to prevent the use of allogeneic blood transfusions and bring cost savings. It depends on the amount of blood loss during the operation. If intraoperative blood loss in the patients who underwent aortic surgery for AAA is compared with the patients operated on for aortic occlusive disease we may say that aortic reconstruction for occlusive disease is associated with lower bleeding, and using the cell salvage technique is ineffective. In terms of AAA repair, blood losses are mostly higher than $1000 \mathrm{ml}$, and administering of Cell Saver device is better justified. Moreover, three meta-analyses assessing ICS in a subpopulation of patients who underwent AAA surgery showed a decrease in the use of allogeneic blood and improvement of clinical outcomes. In addition, the costeffectiveness of the cell salvage technique depends on what type of device is used. The cost of the RBC no-washing type is lower and savings are more evident in this case (Quriel et al. [6]). Nevertheless, it must be taken into account that this technique did not remove harmful debris and contaminants in the scavenged blood with higher risk of complications. And what is more, economically, the set-up for both types of the device has been shown to be cost-effective only when 2 or more units are recovered from the surgical field during the operation and then transfused back into the patient.

Other studies which were published combine the use of the cell salvage technique with acute normovolemic haemodilution.

\section{Acute Normovolemic Haemodilution}

Acute normovolemic haemodilution (ANH) has been used since the 1960 's and is successfully administered to surgical patients. More than 250 papers have been published which assess $\mathrm{ANH}^{21}$. The chief aim of the ANH technique is to avoid or reduce the need for the transfusion of allogeneic blood during the perioperative period, [20,21] moreover, $\mathrm{ANH}$ can also extend the allowable fractional surgical blood loss 
before erythrocyte transfusion is required (the Weiskopf study) [22] and, in contrast to cell salvage (RBC washing device), thrombocytes and coagulation factors are available for transfusion as a part of autotransfusion. Another benefit of this procedure is the improvement in blood fluidity, which results in an increase in venous return and a reduction in the left ventricular afterload; both lead to an increase in cardiac output, mainly through the rise in stroke volume, but also to some increase in heart rate. At the microcirculatory level, improvement in blood fluidity results in an increased red blood cell velocity in the capillaries and an enhanced flow motion. Both mechanisms allow for a better spatial and temporal distribution of red cells within the capillary network, leading to a more homogenous delivery of oxygen to the tissues [23-26]. As described above, the maintenance of tissue oxygenation during $\mathrm{ANH}$ results from an increase in cardiac output and oxygen extraction [27]. Moreover, $\mathrm{ANH}$ is inexpensive; it is the cheapest strategy and the most cost effective among all the options [20].

A theoretical disadvantage of $\mathrm{ANH}$ is that it can lead to dilution of coagulation factors, resulting in higher perioperative bleeding. However, there is no solid evidence to support this concern. A metaanalysis demonstrated that there was no increase in bleeding until the concentration coagulation factors decreased to $20 \%$ of their original value. Even thrombocytopenia and dilutional hyperfibrinogenemia can occur but, in general, the process of ANH encourages a pro-coagulant effect [28-30].

\section{Effectiveness of ANH in saving Allogeneic Blood in Aortic Surgery}

We identified 5 papers in which ANH was assessed as an autotransfusion method in vascular surgery. In 2002, Wong et al. [17] published a multicentre prospective randomized trial which compared the standard transfusion practice with autologous transfusion combining ANH with intraoperative cell salvage. In this study 145 patients undergoing elective aortic surgery (aneurysm, occlusive disease) were randomized and the primary outcome measures were the proportion of patients requiring allogeneic blood and the volume of allogeneic transfusion. The secondary outcome measures were the frequency of complications, including postoperative infection, and postoperative hospital stay. They confirmed that both ANH and intraoperative cell salvage were safe and reduced the allogeneic blood requirement in elective infrarenal aortic surgery. The volume of allogeneic blood transfused was reduced from a median of two units to zero units and the proportion of patients transfused was $56 \%$ in the allogeneic and $43 \%$ in the autologous group (ANH+ICS). There were no significant differences in complications or length of hospital stay.

In the same year, 2002, Torella et al. [31] published a retrospective study of transfusion practice in infrarenal aortic surgery. In this study, 110 patients underwent infrarenal aortic surgery with a combination of acute normovolemic haemodilution (target haemoglobin concentration $11 \mathrm{~g} / \mathrm{dl}$ ) and intraoperative cell salvage. Median blood loss was 1140 $\mathrm{ml}$ in 78 aneurysm repairs and $775 \mathrm{ml}$ in 32 aortobifemoral bypasses for occlusive disease resulting in a median salvaged red cell volume of $403 \mathrm{ml}$ for aneurysm repairs and $250 \mathrm{ml}$ in bypass surgery. Thirty six patients (33\%) needed transfusion of stored blood, a total of 115 units, with just four patients needing more than five units. Mortality rate was $8 \%$. The authors concluded that blood loss was too small to justify intraoperative cell salvage in surgery for occlusive disease and that ANH alone might be a suitable strategy.

And the third study in 2002 was a prospective multicentre randomized trial published by Haynes et al. [31], which evaluated the cost of ANH and intraoperative cell salvage $(n=74)$ vs. allogeneic blood transfusion in aortic surgery $(\mathrm{n}=71)$. Patients who had transfusion of allogeneic blood received some 251 units and those having autologous transfusion $(\mathrm{ANH}+\mathrm{ICS})$ received 103 units $(\mathrm{p}=0.008)$. There was no difference in morbidity, mortality and duration of hospital stay. Transfusion-related mean costs were similar at $\$ 340$ for patients having a homologous transfusion and $\$ 357$ for those receiving autologous blood. Exclusion of a dedicated cell salvage operator reduced autologous transfusion costs but did not have a significant impact on overall cost. The authors demonstrated that autologous transfusion (ICS+ANH) was cost neutral in aortic surgery and led to a decrease in erythrocytes requirements in the autotransfusion group.

\begin{tabular}{|c|c|c|}
\hline Study & Savings in allogeneic blood transfusion & The other benefits of study \\
\hline $\begin{array}{l}\text { Wong }[17](\mathrm{ANH}+\mathrm{ICS}) \\
\text { randomized st. } \\
\mathrm{N}=140\end{array}$ & $\begin{array}{c}\text { Yes } \\
56 \% \text { ALL vs. } 43 \% \text { AUT, } p=0.12 \\
2(0-4) \text { ALL vs. } 0(0-2) \text { AUT unit, } p=0.008\end{array}$ & No differences in complications and hospital stay \\
\hline $\begin{array}{l}\text { Torella [31] }(\mathrm{ANH}+\mathrm{ICS}) \\
\text { retrospective st. } \\
\mathrm{N}=110\end{array}$ & No & $\begin{array}{c}\text { Blood loss was too small to justify cell salvage, ANH is } \\
\text { suitable strategy }\end{array}$ \\
\hline $\begin{array}{l}\text { Haynes [32] }(\mathrm{ANH}+\mathrm{ICS}) \\
\text { randomized st. } \\
\mathrm{N}=72\end{array}$ & $\begin{array}{c}\text { Yes } \\
251 \text { units ALL vs. } 103 \text { AUT, } p=0.008\end{array}$ & $\begin{array}{c}\text { No difference in morbidity, mortality, hospital stay, cost } \\
\text { neutral }\end{array}$ \\
\hline $\begin{array}{l}\text { Wolowczyk [33] (ANH, ICS in both groups) } \\
\text { randomized st } \\
\qquad N=72\end{array}$ & $\begin{array}{c}\text { Yes } \\
2 \text { units AUT vs. } 3 \text { units } A L L, p=0.02\end{array}$ & No difference in postoperative outcome \\
\hline $\begin{array}{l}\text { Wolowczyk [33] (ANH, ICS in both groups) } \\
\text { randomized st } \\
\qquad N=34\end{array}$ & No & - \\
\hline $\begin{array}{l}\text { Wolowczyk [33] (ANH, ICS in both groups) } \\
\text { randomized st } \\
\qquad N=35\end{array}$ & - & No impact on SIRS response \\
\hline $\begin{array}{l}\text { Mannova }[40](\mathrm{ANH}) \\
\text { randomized st } \\
\mathrm{N}=50\end{array}$ & - & $\begin{array}{c}\text { No better toleration of hemodynamic changes during aortic } \\
\text { clamping and de-clamping, no difference in postoperative } \\
\text { myocardial ischemia }\end{array}$ \\
\hline $\begin{array}{l}\text { Tawfick [14] } \\
\text { retrospective cohort st } \\
\mathrm{N}=187\end{array}$ & $\begin{array}{c}\text { Yes } \\
2 \text { or less units AUT vs. } 3 \text { or more units ALL } \\
p<0.0001\end{array}$ & $\begin{array}{c}\text { Yes } \\
+ \text { shorter ICU, hospital stay }\end{array}$ \\
\hline
\end{tabular}

AUT: Autotransfusion group; ALL: Allogeneic group.

Table 2: ANH in aortic infrarenal surgery. 
In 2001 Wolowczyk et al. [33] evaluated the impact of ANH on the blood transfusion requirements in elective abdominal aortic aneurysm surgery (suprarenal and infrarenal clamping). Thirty two patients with ANH were compared with 40 randomly selected patients without ANH where cell salvage was used in both groups. ANH patients required significantly less blood transfusion perioperatively (median 2 units) than the non-ANH patients (median 3 units, $\mathrm{p}=0.02$ ). The authors concluded that, by using ANH effectively, a dedicated team could achieve a significant reduction in the use of heterologous blood transfusion compared to the vascular unit average experience.

On the other hand, two years later, the same authors (Wolowczyk et al. [33]) published another study in which they were more sceptical about ANH. It was a prospective randomized controlled study, carried out on a small sample, with the aim of assessing the impact of standard fluid management on the effectiveness of $\mathrm{ANH}$ as a blood conservation method in elective open AAA repair. Sixteen patients undergoing elective AAA repair were randomized to have ANH and 18 patients as the control group. Intraoperative cell salvage was permitted in both groups. As a result of this study it was found that bank blood transfusion requirements were similar: median 2 units in ANH and 2.5 units in control patients $(\mathrm{p}=0.68)$. The authors concluded that when cell salvage was used with standard fluid management during AAA repair, additional ANH was ineffective in saving blood.

In all the studies mentioned (Table 2), ANH was evaluated as an autotransfusion method in combination with ICS. Three out of four randomized studies (Wong, Haynes, Wolowczyk 2001) found ANH as an effective method and its use led to a reduction in allogeneic transfusion requirements. Only one non-randomized retrospective study (Torella) and one randomized study (Wolowczyk [34]) did not confirm the advantage of ANH in savings in allogeneic blood. On the other hand, even if a decrease in the transfusion requirement was not found, Torella et al. concluded that $\mathrm{ANH}$ alone could be a suitable strategy in contrast to Wolowczyk et al., who assessed ANH as an ineffective method. It should be noted that Wolowczyk et al. [34] randomized only 34 patients in their study from 2003.

\section{Effect of ANH on Microcirculatory and Macrocirculatory Levels}

A benefit of ANH does not have to be only in savings in allogeneic blood. ANH can have a positive impact on the microcirculatory and macrocirculatory levels during aortic surgery. It was found that $\mathrm{ANH}$ can ameliorate ischemia-reperfusion injury in the microcirculation of the skeletal muscle [35,36]. Wolowczyk et al. [37] included 36 patients (one group with ANH and cell salvage and one group with cell salvage only) to determine the effect of $\mathrm{ANH}$ on the inflammatory response and clinical outcome in elective open AAA repair. The outcome measures of this study were markers of the SIRS response in the serum and urine (neutrophil count, C-reactive protein, interleukin 6, total antioxidant capacity, urinary secretion of albumin, retinol binding protein). The authors found no differences in mortality, morbidity rates, systemic inflammatory response syndrome, ICU and hospital stay. Since ANH in combination with cell salvage did not improve the inflammatory response and the clinical outcomes were comparable to the cell salvage alone, the authors concluded that ANH could not be recommended for routine use in patients undergoing AAA surgery and they preferred using the cell salvage technique.

Just as the influence of ANH at the microcirculatory level was studied, some clinical studies demonstrated that ANH preserved the renal function [38] and alleviated the deleterious hemodynamic effect
[37-39] of aortic cross-clamping in patients undergoing abdominal aortic surgery at the macrocirculatory level. The aim of the prospective randomized study (Mannova et al. [40]) was to confirm that patients with ANH would better tolerate aortic clamping and de-clamping within AAA repair in comparison with patients without ANH. The authors predicted that perioperative hemodynamic changes during aortic clamping and de-clamping would be lower and the frequency of ischemic events and postoperative cardiovascular complications would decrease as well. Fifty patients admitted for elective AAA repair were randomized into two groups: patients with $\mathrm{ANH}(\mathrm{n}=25)$ and without ANH $(n=25)$. There was a statistically significant increase in systolic blood pressure (BP syst.), systemic vascular resistance (SVR), decrease in systolic volume (SV), cardiac output (CO), cardiac index (CI) in both groups after aortic clamping $(\mathrm{p}<0.05)$, and a statistically significant decrease in SVR, BP syst., diastolic blood pressure (BP diast), mean arterial pressure (MAP), and an increase in SV, CO, CI after aortic declamping in both groups $(\mathrm{p}<0.05)$. However, a statistically significant difference between the two groups-with ANH and without ANH - was found only in a few parameters: CI after aortic clamping and BP syst., and MAP before de-clamping. Myocardial ischemia, measured by troponin I levels, occurred in 6 patients with ANH and in 8 patients without $\mathrm{ANH}$, there was no statistically significant difference between the two groups. In addition, no statistically significant difference was found in the frequency of perioperative and postoperative complications as well as in cases of renal failure. As the authors concluded, even when there were some positive trends they were not able to determine better toleration of hemodynamic changes in patients with ANH during AAA surgery. Neither of the two studies proved any positive effect of ANH on microcirculation or on hemodynamic changes during aortic clamping and de-clamping. For the future this could be an interesting field for another survey.

\section{To Summarize Acute Normovolemic Haemodilution}

ANH has the potential to be an alternative autotransfusion technique to cell salvage in vascular surgery (Table 2). It is true that a lot of authors are sceptical about this method in vascular surgery and regard this method as ineffective. On the other hand, in published studies this method was assessed together with cell salvage and there were no studies, except one, which would evaluate $\mathrm{ANH}$ as the only autoransfusion method in infrarenal aortic surgery. When ANH was assessed in combination with ICS 3 out of 4 randomized studies confirmed that this combination could be effective in the achievement of the reduction in exposure to allogeneic blood. For all these reasons, another study should be made which would assess the benefits of acute normovolemic haemodilution in reducing allogeneic transfusion requirements, cost savings as well as its potential positive effect on hemodynamic changes during aortic cross-clamping and protection of renal function. Any potential risk of coagulopathy disorders should also be assessed, even if there is no evidence that ANH increases bleeding during operation due to the dilution of coagulation factors or thrombocytopenia.

\section{Conclusion}

We may say that both autotransfusion techniques (ANH and ICS) can be used in elective infrarenal aortic surgery. Both techniques can potentially save allogeneic blood and money but the positive result depends on the amount of blood loss during the surgery, which is frequently higher in abdominal aortic aneurysm surgery. One of these methods -ANH- does not need any special equipment and can be more accessible and its use is cheaper but the other method, the cell 
salvage technique, is more frequently adopted by vascular surgeons and anaesthetists. For the future, acute normovolemic haemodilution should be evaluated in more detail as the only autotransfusion method to judge which technique has more potential benefits in aortic surgery.

\section{References}

1. Rubens FD (2005) An Update on Perioperative Blood Salvage in Cardiac Surgery. Transfusion Alternatives in Transfusion Med 7: 20-27.

2. Freischlag JA (2004) Intraoperative blood salvage in vascular surgery - worth the effort? Crit Care 8 Suppl 2: S53-56.

3. Shulman G (2000) Quality of processed blood for autotransfusion. J Extra Corpor Technol 32: 11-19.

4. Serrick CJ, Scholz M, Melo A, Singh O, Noel D (2003) Quality of red blood cells using autotransfusion devices: a comparative analysis. J Extra Corpor Technol 35: 28-34.

5. Ashworth A, Klein AA (2010) Cell salvage as part of a blood conservation strategy in anaesthesia. Br J Anaesth 105: 401-416.

6. Ouriel K, Shortell CK, Green RM, DeWeese JA (1993) Intraoperative autotransfusion in aortic surgery. J Vasc Surg 18: 16-22.

7. Davies L, Brown TJ, Haynes S, Payne K, Elliott RA, et al. (2006) CostEffectiveness of Cell Salvage and Alternative Methods of Minimising Perioperative Allogeneic Blood Transfusion: A Systematic Review and Economic Model. Health Technology Assessment 44: 201-210.

8. Clagett GP, Valentine RJ, Jackson MR, Mathison C, Kakish HB, et al. (1999) A randomized trial of intraoperative autotransfusion during aortic surgery. J Vasc Surg 29: 22-30.

9. Spark JI, Chetter IC, Kester RC, Scott DJ (1997) Allogeneic versus autologous blood during abdominal aortic aneurysm surgery. Eur J Vasc Endovasc Surg 14: $482-486$

10. Kelley-Patteson C, Ammar AD, Kelley H (1993) Should the Cell Save Autotransfusion Device be used routinely in all infrarenal abdominal aortic bypass operations? J Vasc Surg 18: 261-265.

11. Mercer KG, Spark JI, Berridge DC, Kent PJ, Scott DJ (2004) Randomized clinical trial of intraoperative autotransfusion in surgery for abdominal aortic aneurysm. Br J Surg 91: 1443-1448

12. Huber TS, Carlton LC, Irwin PB, Flug RR, Harward TRS, et al. (1997) Intraoperative autologous transfusion during elective infrarenal aortic reconstruction. J Surg Res 67: 14-20.

13. Goodnough LT, Monk TG, Sicard G, Satterfield SA, Allen B, et al. (1996) Intraoperative salvage in patients undergoing elective abdominal aortic aneurysm repair: an analysis of cost and benefit. J Vasc Surg 24: 213-218.

14. Tawfick WA, O'Connor M, Hynes N, Sultan S (2008) Implementation of the Continous AutoTransfusion System (C.A.T.S.) in open abdominal aortic aneurysm repair: an observational comparative cohort study. Vasc Endovascular Surg 42: 32-33.

15. Alvarez GG, Fergusson DA, Neilipovitz DT, Hébert PC (2004) Cell salvage does not minimize perioperative allogeneic blood transfusion in abdominal vascular surgery: a systematic review. Can J Anaesth 51: 425-431.

16. Takagi H, Sekino S, Kato T, Matsuno Y, Umemoto T (2007) Intraoperative autotransfusion in abdominal aortic aneurysm surgery: meta-analysis of randomized controlled trials. Arch Surg 142: 1098-1101.

17. Wong JC, Torella F, Haynes SL, Dalrymple K, Mortimer AJ, et al. (2002) Autologous versus allogeneic transfusion in aortic surgery: a multicente randomized clinical trial. Ann Surg 235: 145-151.

18. Tavare AN, Parvizi N (2011) Does use of intraoperative cell-salvage delay recovery in patients undergoing elective abdominal aortic surgery? Interact Cardiovasc Thorac Surg 12: 1028-1032.

19. Shantikumar S, Patel S, Handa A(2011) The role of cell salvage autotransfusion in abdominal aortic aneurysm surgery. Eur J Vasc Endovasc Surg 42: 577-584.

20. Torres De Araújo L M, Gracia LV (2013) Acute Normovolemic hemodilution: A Practical Approach. Open Journal of Anesthesiology 3: 38-43.

21. Van derLinden P, Sakr P (2005) Acute Normovolemic Hemodilution in Cardiac Surgery. Transfusion Alternatives in Transfusion Medicine 7: 11-19.
22. Weiskopf RB (2001) Efficacy of acute normovolemic hemodilution assessed as a function of fraction of blood volume lost. Anesthesiology 94: 439-446.

23. Kreimeier U, Messmer K (2002) Perioperative hemodilution. Transfus Apher Sci 27: 59-72.

24. Martin E, Hansen E, Peter K (1987) Acute limited normovolemic hemodilution: a method for avoiding homologous transfusion. World J Surg 11: 53-59.

25. Messer K, Gutierrey G, Vincent JL (1991) Blood rheology factors and capillary blood flow In Tissue Oxygen Utilization. Berlin, Heidelberg, Springer-Verlag, New-York, pp: 103-113

26. Lipowsky HH, Firrell JC (1986) Microvascular hemodynamics during systemic hemodilution and hemoconcentration. Am J Physiol 250: H908-922.

27. Vara-Thorbeck R, Guerero-Fernandes Marcote JA (1985) Haemodynamic response of elderly patients undergoing major surgery under moderate normovolemic hemodilution. Eur Surg Res 17: 372-376.

28. Martin E, Ott E (1981) Extreme hemodilution in the Harrington procedure. Bibl Haematol : 322-337.

29. Bryson GL, Laupacis A, Wells GA (1998) Does Acute Normovolemic Hemodilution Reduce Perioperative Allogeneic Transfusion? A Meta-Analysis. Anesthesia and Analgesia 86: 9-15.

30. Hill S, Carless PA, Henry DA, Carson JL, Hebert PPC, et al. (2002) Transfusion Thresholds and Other Strategies for Guiding Allogeneic Red Blood Cell Transfusaion. Cochrane Database of Systematic Reviews 2: CD002042

31. Torella F, Haynes SL, Kirwan CC, Bhatt AN, McCollum CN (2002) Acute normovolemic hemodilution and intraoperative cell salvage in aortic surgery. J Vasc Surg 36: 31-34

32. Haynes SL, Torella F, Wong JC, Dalrymple K, James M, et al. (2002) Economic evaluation of a randomized clinical trial of haemodilution with cell salvage in aortic surgery. Br J Surg 89: 731-736.

33. Wolowczyk L, Lewis DR, Nevin M, Smith FCT, Baird RN, et al. (2001) The Effect of Acute Normovolemic Haemodilution on Blood Transfusion Requirements in Abdominal Aortic Aneurysm Repair. EJ of Vasc Endovasc Surg 22: 361-364.

34. Wolowczyk L, Nevin M, Smith FC, Baird RN, Lamont PM (2003) Haemodilutional effect of standard fluid management limits the effectiveness of acute normovolaemic haemodilution in AAA surgery--results of a pilot trial. Eur J Vasc Endovasc Surg 26: 405-411.

35. Menger MD, Sack FU, Barker JH, Feifel G, Messmer K (1988) Quantitative analysis of microcirculatory disorders after ischemia in skeletal muscle. Therapeutic effect of prophylactic isovolemic hemodilution. Res Exp Med 188 151-165.

36. Frost-Arner L, Wellander E, Mattsson E, Bergqvist D (1998) Isovolemic hemodilution and skeletal muscle function during ischemia and reperfusion. Microsurgery 18: 79-85.

37. Wolowczyk L, Nevin M, Day A, Smith FCT, Baird RN, et al. (2005) The Effect of Acute Normovolemic Haemodilution on the Inflammatory Response and Clinical Outcome in Abdominal Aortic Aneurysm Repair-Result of a Pilot Trial. Eur J Vasc Endovasc Surg 30: 12-19.

38. Welch M, Knight DG, Carr HM, Smyth JV, Walker MG (1993) The preservation of renal function by isovolemic hemodilution during aortic operations. J Vasc Surg 18: 858-866.

39. Catoire P, Saada M, Liu N, Delaunay L, Rauss A, et al. (1992) Effect of preoperative normovolemic hemodilution on left ventricular segmental wall motion during abdominal aortic surgery. Anesth Anal 75: 654-659.

40. Mannova J, Silhart Z, Sevcik P (2007) Altering the hemodynamics during abdominal aortic aneurysm repair by acute normovolemic hemodilution. Anest Intens Med 3: 141-149.

Citation: Mannova J, Silhart Z, Prokes (2014) Blood Transfusion Strategies in Elective Vascular Surgery. J Blood Disorders Transf 5: 233. doi: 10.4172/21559864.1000233 